\title{
Tarmbakterier og immunceller samarbeider
}

\section{Glykosylering av tarmepitelet er viktig for å forebygge infeksjoner. Dette skjer i et samspill mellom tarmflora og immunsystem.}

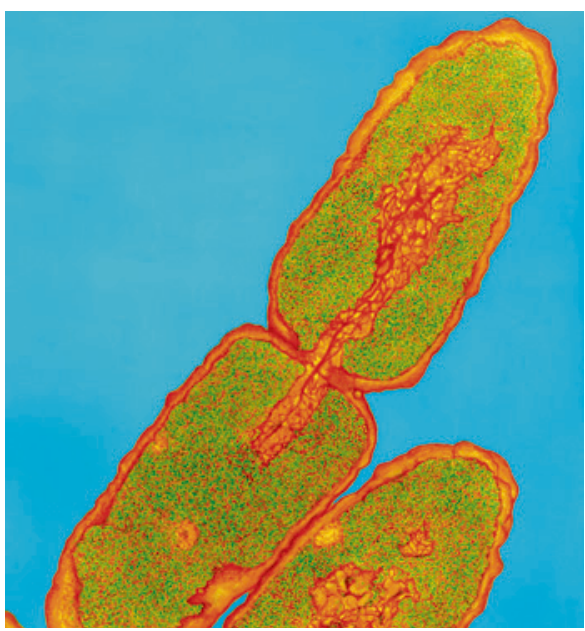

Salmonella typhimurium bacteria. Illustrasjonsfoto Sciencephoto/NTB scanpix
Tarmslimhinnens immunsystem bidrar til å opprettholde tarmens mikrobiotiske homeøstase. Dette krever at overflaten på epitelialcellene glykosyleres. En hovedmekanisme er fukosylering, som katalyseres av fukosyltransferase 2 (Fut2). Det er uklart hvordan denne prosessen reguleres. En internasjonal forskergruppe har nå studert dette i genmodifiserte mus (1).

Resultatene fra studien viste at de lymfoide cellene ILC3 i det medfødte immunsystemet induserte Fut2-ekspresjon og fukosylering i tarmepitelet. Fukosyleringen var avhengig av at ILC3-cellene produserte bestemte cytokiner, sannsynligvis som respons på signaler fra tarmbakterier. Mus som manglet Fut2, var mer utsatt for infeksjon av Salmonella typhimurium enn kontrollmus.

- Tarmepitelcellene «sukrer» celleoverflaten sin med fukoseforbindelser, trolig for å mate normalfloraen og holde unna patogene mikrober, sier lege og forsker Jørgen Valeur ved Lovisenberg Diakonale Sykehus. - Epitelcellenes evne til å lage slike fukoseforbindelser opprettholdes av fukosespisende bakterier i normalfloraen, ikke minst av Bactero- ides thetaiotaomicron. Dette samspillet er ikke kjent i detalj, sier han.

- I denne studien har man vist at immunsystemet, spesielt de såkalte ILC3-cellene, kan være et viktig mellomledd. Hvordan tarmfloraen signaliserer til ILC3-cellene, ble imidlertid ikke undersøkt. I en tid hvor den mikrobielle endokrinologien er i ferd med å bli etablert som selvstendig fagfelt, burde man studere dette nærmere, sier Valeur.

Trine B. Haugen

Tidsskriftet

\section{Litteratur}

1. Goto Y, Obata T, Kunisawa J et al. Innate lymphoid cells regulate intestinal epithelial cell glycosylation. Science 2014; 345: 1254009. E-publisert 21.8.

\section{Ulike slankedietter er like gode}

\author{
Effekten av forskjellige kommersielle slankedietter hos overvektige \\ er stort sett den samme. Dette viser en ny metaanalyse.
}

Metaanalysen omfattet 59 studier med til sammen rundt 7000 personer med en kroppsmasseindeks (BMI) på $\geq 25 \mathrm{~kg} / \mathrm{m}^{2}$ som ble undersøkt etter minst tre måneder på ulike dietter (1). Såkalte lavkarbodietter ga størst vekttap (gjennomsnittlig nesten $9 \mathrm{~kg}$ etter seks måneder og over $7 \mathrm{~kg}$ etter 12 måneder). Dietter med lavt fettinnhold ga omtrent samme vektreduksjon.

- Denne metaanalysen av studier med kommersielle vektreduksjonsdietter bekrefter tidligere oversiktsartikler som tyder på at ingen spesifikke dietter skiller seg ut som spesielt gode eller spesielt dårlige, sier Jøran Hjelmesæth, som er leder av Senter for sykelig overvekt i Helse Sør-Øst, Sykehuset i Vestfold, og professor ved Universitetet i Oslo.

- I metaanalysen har man brukt den anerkjente GRADE-metodikken til systematisk å evaluere kvaliteten på studiene og tiltroen til effektestimatene, men analysen omfatter kun kommersielt tilgjengelig dietter. Resultatene kan derfor ikke generaliseres til ikke- kommersielle vektreduksjonsprogrammer eller retningslinjer, påpeker han.

- Den har heller ikke med data for varig vektendring - ett år er rett og slett for tidlig til å si noe om dette. Jeg savner også data om effekten på blodglukose, lipider og blodtrykk og opplysninger om eventuelle bivirkninger, sier Hjelmesæth.

\section{Tor Atle Rosness}

Tidsskriftet

\section{Litteratur}

1. Johnston BC, Kanters S, Bandayrel Ket al. Comparison of weight loss among named diet programs in overweight and obese adults: a metaanalysis. JAMA 2014; 312: 923-33.

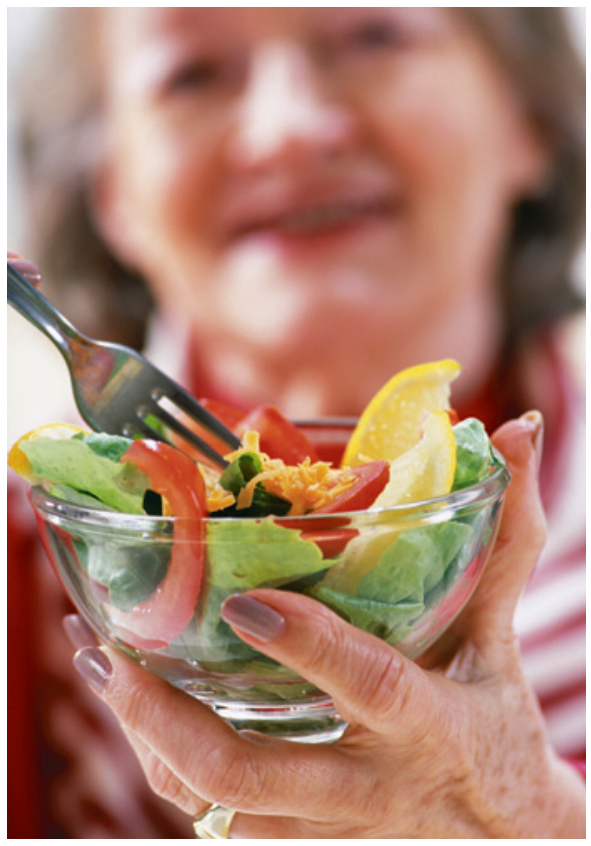

llustrasjonsfoto: Sciencephoto/NTB scanpix 